\title{
Philip Wood
}

\section{Christian Elite Networks in the Jazīra, c.730-850}

\begin{abstract}
A major survival from the Roman Near East that endured within the caliphate was the episcopal and monastic networks making up the different Christian denominations. This article draws on the Chronicle of Michael the Syrian to illustrate how the caliphate became an increasingly hostile environment for Christian landed lay elites, incentivizing powerful families to take roles in the state's administration or within the church. Using examples from the Jacobite church, I argue that the state became increasingly involved in church governance, by publicly endorsing the patriarch and his ability to raise revenues from Christians, and by supporting him with state troops against rival clerics.
\end{abstract}

Keywords: Caliphate; Jacobite; patriarchate; Jazīra; Edessa; taxation; elites

\section{Introduction}

Chris Wickham defines aristocrats in the period $300-800$ by their ability to remember their ancestry; their control of land and official position; their expensive lifestyles; their mutual recognition; and their ability to control Königsnähe (proximity to royal influence). ${ }^{1}$ The relative importance of these characteristics ebbed and flowed with the importance of the state: for example, official position and court influence were particularly important for Roman aristocracies but dwindled in value in the weaker states of the post-Roman West. ${ }^{2}$ The manner through which later aristocrats demonstrated their elite status also differed markedly: the cultural capital of the elite of the early medieval West became much less literary and more military. ${ }^{3}$

The caliphate differed from other post-Roman polities in its maintenance of a Muslim monopoly over military service. Crucial means of signalling Christians' subordinate status included their obligation to pay the jizya and a ban on their

This paper is an initial exploration of ideas that I intend to develop into a monograph. I am very grateful to Stefan Heidemann and Hannah Hagemann for the invitation to the conference in Hamburg in 2016 for which I wrote an initial version of this paper.

1 Wickham 2005, 154.

2 Wickham 2005, 156-162, 176.

3 Halsall 2007, 495- 497.

Ә OpenAccess. ( 2020 Philip Wood, published by De Gruyter. (cc) BY-NC-ND This work is licensed under the Creative Commons Attribution-NonCommercial-NoDerivatives 4.0 License. 
riding horses or bearing arms. ${ }^{4}$ Christian elites were therefore denied military experience and this restricted their potential to challenge the state. They were also deprived of the forms of masculine display typical of many of their ancestors. ${ }^{5}$ For some this deprivation may have been an incentive to convert to Islam. ${ }^{6}$

However, one important similarity between the caliphate and other postRoman states was the retention of episcopal and monastic networks. We should see the episcopal network in particular as a survival of the Roman administration, or (in the case of the Sasanian world) as an imitation of it. Church institutions had developed in the context of an intrusive bureaucratic government, ${ }^{7}$ and its members both served as agents of the state and were empowered to resist its demands.

I focus in this paper on the Jazira, defined here as the lands between Amida, Aleppo and Mosul, with occasional glances south-west to Syria and south-east to Takrit and Baghdad. This geographical perspective is drawn from the Syriac chronicles of Michael the Syrian and Bar Hebraeus, whose works preserve quotations from earlier chronicles. Where we can isolate his testimony within these later works, the history of Dionysius of Tel-Mahre (Jacobite patriarch of Antioch, d. 846) is particularly important. ${ }^{8}$ Though we must always be careful not to take his words at face value, his interest in elite lineage (including his own), in relations with Muslim authorities and in the repetition of patterns in church politics makes the medieval compilations that used his history a significant source for any investigation of political networks in this period.

4 Wood 2015, 39-40. Arab Christians did, however, participate in the early conquests: Donner 2010, 192. Noth 2004, 13, argues that restrictions on Christians bearing arms were not a significant handicap since most Christians were city-dwellers. I strongly disagree: this reads back the effects of this kind of restriction as a 'natural' characteristic of Christians in the region. For the military values of Sasanian Christians in the $7^{\text {th }}$ century, see Walker 2006. For the post-conquest period, see Cobb 2001, 114-116 (on Mount Lebanon); Thomas of Marga, Book of Governors, V. xiii (294/523 ff.) (on the warlike village of Zarn in northern Iraq); Chronicle of Zuqnin, 196/171 ff. (on the raising of Christian war-bands in the Jazìra during the 'Abbāsid revolution).

5 Wood 2015, 43-47.

6 An important category of early converts were prisoners of war, who thus retained a position where they could put their military skills to use. The classic example are the asāwira, the elite cavalry of the Sasanian army, who became members of the Banū Tamīm: Morony 1983, 271-272; Zakeri 1995, 190.

7 Chamberlain 1994.

8 The reconstruction of Dionysius' Chronicle is part of an on-going project by Peter Van Nuffelen and Maria Conterno at Ghent, and I have benefited greatly from the preliminary results of their project. 


\section{Christian Confessions and Episcopal Structures}

Three major Christian confessions were active in the Near East at the time of the Arab conquests.

The Chalcedonians (the so-called Melkites) were approved by the Roman Empire and in communion with Catholic Christians in Western Europe. They originally used Greek as a liturgical language, but were the first confession to switch to an Arabic liturgy. ${ }^{9}$

The Miaphysites were concentrated in rural Syria, Mesopotamia and Egypt. They differed from the Chalcedonians on important points of doctrine, but never uniformly condemned the authority of the Roman emperor. In the $6^{\text {th }}$ century at least they should be seen as an orthodoxy in waiting, gradually distancing themselves from the memory of Roman authority and Roman imperial support. ${ }^{10}$ By the $7^{\text {th }}$ century they employed Syriac in their liturgy and religious writing, ${ }^{11}$ but this is more a consequence of Miaphysite displacement into rural areas where Greek was not spoken than deliberate policy on the part of church leaders. ${ }^{12}$ This $6^{\text {th }}$-century displacement also meant it was the Miaphysites rather than the Chalcedonians ${ }^{13}$ who were active as missionaries on the frontiers of the Roman world; most notably in the Arabian Peninsula, ${ }^{14}$ Iraq $^{15}$ and the Jazira. ${ }^{16}$ Within this group, I differentiate between two factions, the Jacobites and Julianists, who were still present under the caliphate. Of these the Jacobites were by far the larger and more powerful.

Finally, the Church of the East, sometimes problematically referred to as the Nestorian church, ${ }^{17}$ was the chief Christian organization within the Sasanian Empire. They too employed Syriac, which served as a Christian high-dialect for speakers of various forms of Aramaic across the Fertile Crescent. ${ }^{18}$ Though the Church of the East shared many traditions with the Miaphysites, they were starkly different in their theology, a difference that became ever more exaggerated from the start of the $7^{\text {th }}$ century. ${ }^{19}$

9 Griffith 2008, 138; Griffith 1998.

10 Wood 2010, 256.

11 van Rompay 2008; Hage 1996, 57-58.

12 Wood 2010, 173-175.

13 Ivanov 2015.

14 Wood forthcoming.

15 Fiey 1970a, 127.

16 Life of Ahudemmeh, PO 3.

17 Brock 1996.

18 Taylor 2002.

19 Chediath 1982. 
Both the Roman and Sasanian empires were interventionist bureaucratic states. This shaped the experience and expectations of the Christian episcopate. Church institutions came to mirror the bureaucracy of the secular state, most explicitly in the Roman Empire, where the episcopate was an extension of the imperial bureaucracy (if a sometimes independent-minded one). ${ }^{20}$ The empire accorded bishops roles as arbitrators and gave church councils the force of imperial law. ${ }^{21}$ Bishops also played a role in wider networks of secular elites, both military figures and bureaucrats. Letter collections show them interceding for friends and clients to obtain patronage ${ }^{22}$ and petitioning for tax remissions for individuals, cities and monasteries. ${ }^{23}$ While bishops never had a state-sanctioned role as judges in the Sasanian world, they aspired to this role (if only for Christian communities) ${ }^{24}$ and occupied it in practice after the collapse of Sasanian authority in the $640 \mathrm{~s}^{25}$

\section{Christian Lay Elites and the Caliphate}

In some parts of the early caliphate, the Jazira in particular, the Arab conquests generated an 'Indian summer' because the new regime was much less intrusive than the Sasanian and Roman states that preceded it. ${ }^{26}$ The weakness of the Sufyānid state in this region meant increased leeway for regional magnates, such as the shahregan of Marga, to accumulate massive wealth. Some of these figures were Christians and spent fortunes on founding a swathe of new monasteries in northern Iraq between 580 and $720 .{ }^{27}$ The same period saw a similar burst in the construction of Jacobite churches and monasteries in the Țūr 'Abdīn, though probably on a rather smaller scale. ${ }^{28}$

20 Jones 1964, chp. 22; Liebeschuetz 2001, 139-140 and 145-155.

21 Humfress 2005.

22 Schor 2011; Brown 1992, 106-109.

23 Rapp 2005, 261 (on Cyrene); Brown 1992, 144 (on Sohag), 151 (on peasants near Antioch).

24 Payne 2015, chp. 3; Wood 2013, chp. 4.

25 Payne 2014.

26 Robinson 2000, 50-62.

27 Wood 2017. These monastic foundations are the subject of an archaeological survey by Karel Novaček et al. at Prague University.

28 Palmer 1990, 186-187, notes the prosperity of the monasteries in contrast to the villages and suggests that this may stem from tax exemptions as well as elite protection. For the distribution of these churches and monasteries, and dating using architectural features, see Keser-Kayaalp 2013; Keser-Kayaalp 2016. 
The hagiographic collection of Thomas of Marga, written in the 840s, represents the Umayyad period as a time of contest between these Christian lay elites and the monasteries that they founded. Some of the monastic hagiography set in this period can be read as statements on the ideal autonomy of monasteries and the secondary status of the men who founded them. Such statements were necessary because founding aristocrats were not always ready to relinquish control.

The tightening of the state under the 'Abbāsids is represented as a catastrophe for the shahregan as a class. ${ }^{29}$ However, Christians with different kinds of skills and cultural capital benefited greatly from the expansion of the state. Even as the rural peasantry suffered from the application of the poll tax, ${ }^{30}$ the Christian administrative class was employed in implementing the new taxation systems, drawing on skills developed during the Roman and Sasanian period. Sarjūn b. Manșūr (fl. 690s), father of John of Damascus, and Athanasius bar Gumaye (fl. 690s), an ancestor of the Jacobite patriarch Dionysius of Tel-Mahre (r. 818-845), are good early examples of Christians in charge of tax collection on behalf of the caliph. Service for the state brought great rewards for both men, channelled into investment in his home-town (in the case of Athanasius) and political influence deployed in regional competition between Christian confessions (in the case of Sergius). ${ }^{31}$

The drift of the administration towards the use of Arabic, even if it was intended to disempower non-Arab administrators, probably had the effect of accelerating a change in Christian language use away from Greek (and to a lesser extent Syriac) and towards Arabic. ${ }^{32}$ Arabic became the language of young men aspiring to a role in government, and educational establishments followed suit. Vollandt argues that this switch began first in Melkite Palestine, where the Sabaite monasteries were early adopters of Arabic education in the $8^{\text {th }}$ century. ${ }^{33}$ 'Nestorian' centres near Baghdad followed suit from the $9^{\text {th }}$ century. Jacobites, who were located further from longstanding centres of caliphal power, were the last to adopt the new language. However, we can further divide the Ja-

29 E. g. Thomas of Marga, Book of Governors, III. iii (150/307 ff.) for the fall-out from the imposition of 'Abbāsid government. See Robinson 2000, 82-83. Cf. Robinson 2016.

30 Chronicle of Zuqnin, 154/147, for the census of 'Abd al-Malik. Later sections of the Chronicle provides rich evidence for the imposition of taxes and a census in the Abbasid period.

31 Debié 2016. The Manșūr family are accused of denouncing Athanasius to the caliph and of facilitating the promotion of Chalcedonians in Syria by getting the local governor to ban an addition to the Trisagion prayer used by Miaphysites and Maronites. Chronicle of Michael the Syrian (MS) XI. 20 (IV 248/II 492).

32 For the a wider discussion of the relative fates of Greek, Aramaic, Arabic and Coptic: Hoyland 2003; Papaconstantinou 2012; Wasserstein 2003.

33 Leeming 2003; Griffith 1989; Griffith 1998. 
cobites between the eastern Jacobites, with their centre at Takrit, and the western Jacobites, with significant centres in the Țūr 'Abdīn and in Edessa and Amida. Proximity to large sites of Arab settlement in Iraq meant that the eastern Jacobites adopted Arabic much faster, and eastern Jacobites were producing philosophy in Arabic by the early $9^{\text {th }}$ century. ${ }^{34}$

Thus there were regional exceptions to the general trend towards the Christian use of Arabic by Christians and the importance of Christian 'middle-class' professions. In Marga, even in the 'Abbāsid period, the shahregan continued to expect to dominate episcopal elections ${ }^{35}$ and to fund monasteries out of personal wealth and have them named after them. ${ }^{36}$ And even at the end of the Book of Governors, one gets the impression that Arabs were present in this region only in small numbers and that knowledge of Arabic by Christians was exceptional. Likewise, the region of Edessa that is described by Dionysius of Tel-Mahre does not seem to have produced the dominant class of secretaries or physicians in the $9^{\text {th }}$ century that occur in Mārī b. Sulaymān's description of Baghdad. ${ }^{37}$ One Jacobite patriarch, George of Beltan (d. 790), a native of Emesa, suffered for his inability to communicate in Arabic at court, and his faux-pas of swearing in Greek before the caliph is said to have led to his imprisonment. ${ }^{38}$

\section{Monopoly of Access and the Clerical Hierarchy}

Christian episcopal structures in the Roman world operated in hierarchies based on provincial organization. Patriarchs, metropolitans, archbishops and bishops occupied successive ranks within this hierarchy, which was signalled publically by the laying on of hands at a candidate's consecration to a new rank and by the reading out of the names of bishops during the liturgy. But there was always tension in this ranked system. What right did a patriarch have to intervene in the

34 Vollandt 2015, 27-33.

35 See Thomas of Marga, Book of Governors, IV.v-vi, for their refusal to accept Ishoyahb of Marga as metropolitan of Adiabene after he is appointed by Timothy the patriarch.

36 Thomas of Marga, Book of Governors, V.ii (for the Hiran ascetic Shubhalisho and his foundation of Beth Habba) and VI.Xii (for the naming of a monastery after Nerab Barzai, who funded a nearby cistern). Thomas has little sympathy with monks who resent these acts of charity as unwarranted external interference.

37 Cf. Cabrol 2012; Cabrol 2000.

38 MS XI. 26 (IV, 476/II, 528). For professional opportunities for Christians in Baghdad, see Putman 1975. 
consecration of bishops by his archbishops? ${ }^{39}$ And what right did citizens of a town have to refuse the imposition of a bishop ${ }^{40}$

At the same time, clerical hierarchies also had an ambiguous relationship to parallel monastic and lay hierarchies. In the Roman Empire, the emperor had convened the great councils of the church to agree on orthodox doctrine and the excommunication of dissenters. This legacy left churches within the caliphate uncertain who could legitimately convene a council, especially in conditions where there were multiple claimants to the patriarchate or no sitting patriarch.

The history of the Jacobite church as an organization that evolved an episcopal structure during rural exile also gave monasteries a close relationship to the patriarchate. Monasteries such as Qenneshre, Qartmin and Gubba Barraya were traditionally nurseries of the patriarchate and could prove hotbeds of opposition to patriarchs who did not come from this background. ${ }^{41}$

The relatively decentralized and rural composition of the Jacobite church meant that bishops could find it hard to maintain their prerogatives according to church canons. $9^{\text {th }}$-century canonists condemned the practice of laypeople going to those other than bishops for judgement, whether those chosen were monks ${ }^{42}$ or powerful laymen (the laymen in question may have been Christian magnates or local Muslim leaders). ${ }^{43}$ Other canons further condemned those who appealed to laymen to intervene in theological quarrels ${ }^{44}$ or excommunicated members of the lower clergy who ask Muslim leaders to overturn decisions. ${ }^{45}$ It is worth stressing that the concern of these canons was to insulate Christians from Muslim jurisdiction while also asserting the rights of the clergy over lay and monastic rivals. Both the division of society according to religion and the cleric-

39 E.g. MS XI.22 (IV, 466/II, 508), where bishop Bacchus of Nineveh and the monks of Mar Mattai were condemned at the council of Reshaina for ordaining bishops without the consent of the metropolitan of Takrit.

40 E. g. MS XII. 5 (IV, 489/III, 19), for the rejection of Cyriacus' candidate for Cyrrhus (with comments of Oez 2012, II, 48). See Norton 2007, 34, 63-66, for comparisons to the late Roman period.

41 The appendix to MS gives the training and places of ordination for all the Jacobite patriarchs, which makes the dominance of these monasteries in the $6^{\text {th }}-9^{\text {th }}$ centuries very clear. Also note Chronicle of Zuqnin, 244-245/217-218, for his comments on the arrogance of bishops drawn from 'famous monasteries'. See here the comments of Oez 2012, II, 38.

42 Synod of Dionysius II, canons 8 and 10 (Vööbus 1976, 60-61/64-65).

43 Synod of Ignatios, canon 4 (Vööbus 1976, 53/57).

44 Synod of Cyriacus canon 14 (Vööbus 1976, 21/23).

45 Synod of Dionysius of Tel-Mahre, canon 4 (Vööbus 1976, 29/32). Parallels occur in the Church of the East at the synod of Henanisho II in 778 (Chabot 1902, 245-250/515-521). 
alisation of leadership within dhimmi communities should seen as important features of 'Abbāsid society. ${ }^{46}$

Such shrill condemnations indicate the church's reliance on symbolic power. Bishops could impose bans on communion or acts of penance, but their ability to enforce such penalties was limited. ${ }^{47}$ There were occasions where bishops acted on behalf of the caliph and were empowered to act as judges, ${ }^{48}$ but even then the authority of a given bishop relied on other Christians agreeing to his decisions. A patriarch who regularly required coercive backup from the state would not have been seen as an effective manager of his co-religionists.

If we conceive of Muslim and Christian governance structures as independent hierarchies, then it was in the interests of a patriarch to monopolise interactions between those two hierarchies and to ensure he alone spoke on behalf of the caliphal government before his co-religionists. Wherever his subordinates were able to secure the support of a local emir, or worse still the caliph, his ability to guarantee his judgements or secure patronage was diluted.

A good example of the chaos that might emerge when a patriarch lost his monopoly of access to Muslim authority is the period around 740-750. This period was dominated by Athanasius Sandalaya, the metropolitan of Maypherkat, and characterized by the use of royal influence by figures other than the patriarch. For instance, one Cyriacus of Segestan, together with a doctor named Bar Salta of Reshaina, composed an apocalypse foretelling the rule of the descendants of Marwān II. ${ }^{49}$ Marwān rewarded this act of sycophancy by proclaiming Cyriacus bishop of Ṭūr 'Abdīn, although it contravened the rules against the transfer of episcopal sees and the rights of the higher bishops to fill the see. ${ }^{50}$ It was not possible to excommunicate Cyriacus until 'the tyrant who protected him had died'. ${ }^{51}$ The historian can only present his condemnation of Marwān and Cyriacus in such stark terms because of the collapse of the Umayyad dynasty with the 'Abbāsid revolution: in other circumstances commentators may have been more circumspect.

46 See Papaconstantinou 2008.

47 Simonsohn 2010; Simonsohn 2011, 154-155.

48 Simonsohn 2011. Edelby 1951 remains important and useful. Note, for instance, the scene in the Life of Theodota of Amida (§ 156) where the saint is made responsible for 'the laws of the city of Amida' after being elected bishop. There is no sense, however, that this is an automatic function of his office, and in the Life as a whole the norm is for laymen bearing Greek names to hold office on behalf of the caliph. Payne 2009, 407-408, and Papaconstantinou 2008, 145, observe the predominance of lay elites in $7^{\text {th }}$-century Nisibis and Egypt respectively.

49 MS XI. 22 (IV, 464/II, 507).

50 Hage 1966, 35.

51 MS XI. 22 (IV, 466/II, 507). 
The importance of courtly influence is even more apparent in the case of Sandalaya himself, who enjoyed close links to Marwān's government. Sanadalaya accused the patriarch Iwannis of simony (the sale of ecclesiastical office) to Marwān II, and was accused in turn of paying massive bribes to the caliph. Sandalaya and six other bishops were subsequently excommunicated at a synod at Harrān (750) organized by the metropolitan David of Dārā. It is striking that neither David nor the patriarch felt able to carry the other bishops and appealed to the caliph to send a neutral bishop to act as an arbitrator. ${ }^{52}$

Michael's Chronicle represents Sandalaya as temporarily humiliated at Harrān, but he managed to restores his dominance by interceding with the caliph's brother 'Abdallāh at a later synod at Tella (752). 'Abdallāh also secured Sandalaya's promotion as metropolitan of Maypherkat..$^{53}$ In canonical terms, this is especially striking because Maypherkat was not a metropolitanate: the city's prestige increased alongside Sandalaya's. It may be that Sandalaya took this route because Maypherkat was a power base for him personally (for unstated reasons of family background or influence).${ }^{54}$ At any rate, Sandalaya's promotion was followed by his endowment of a major church at Maypherkat and a monastery at Tell-Bashmai. ${ }^{55}$

Exactly how the office generated this revenue is unclear. If we compare bishops to highly ranked $q \bar{a} d \underline{\imath} \mathrm{s}$, then we might envisage that a role as a judge offered opportunities for substantial bribes or influence. ${ }^{56}$ One novelty in the 'Abbāsid period was that bishops were able to levy a tithe on their parishioners (though the fair level of these tithes was a matter for debate). ${ }^{57}$ Straightforward simony may also have been a means of raising money or generating influence. ${ }^{58}$ Sandalaya's career as metropolitan (and briefly as patriarch) was characterized by attempts to impose candidates on unwilling sees ${ }^{59}$ and the division of sees into

52 MS XI. 23 (IV, 468/II, 512).

53 MS XI. 23 (IV, 469/II, 514).

54 Hage 1966, 32.

55 MS XI. 23 (IV, 469/II, 514); Chronicle of Zuqnin, 210/192.

56 Wickham 2014.

57 The first explicit references to church taxes are the accusations made against the patriarch George by David of Dārā: MS XI. 26 (IV, 476/II, 526).

58 Hage 1966, 35.

59 MS XI. 15 (IV, 471/II, 520), for his division of the see of the Țūr 'Abdīn between Gabriel of Qartmin and Cyriacus of Segestan, in defiance of the will of the patriarch Ishaq. Iwannis' attempt to divide the disocese of Amida may have had a similar motivation (MS 467/509). 
smaller units, ${ }^{60}$ both of which may represent attempts to pay back substantial initial investments. The construction of the church at Maypherkat could also be seen as the repayment of a (political) debt incurred in Sandalaya's quest for promotion.

Where a patriarch failed to inspire confidence in his bishops or monopolise access to higher authorities, it opened the door to other bishops like Cyriacus of Segestan or Athanasius Sandalaya to use their own contacts with Muslim leaders to assure promotion. In so doing they damaged established conventions for church governance and undermined the authority of the office of the patriarch.

\section{Established Churches}

If the patriarch aspired to monopolise contacts with the caliph and his agents, we should remember that the caliph benefited from Christian governmental structures that could be used to raise taxes or to ensure the regime had a measure of legitimacy for its Christian population (which was probably in the majority in many regions at this time, including the Jazira). Individual caliphs also used the higher clergy for their distinctive skills: for their diplomatic connections to Christian states such as Byzantium ${ }^{61}$ and Nubia; ${ }^{62}$ to intervene in the governance of Christian populations in other provinces; ${ }^{63}$ and for their mastery of arcane knowledge (such as alchemy). ${ }^{64}$ In addition, the presence of the patriarch at court also served to legitimize the caliph as a just ruler before his Muslim sub-

60 MS XI. 15 (IV, 471/II, 520), for his consecration of new bishops for Sinjār and Samosata as well as the Țūr 'Abdīn. Cyriacus of Segestan's consecration in the Țūr 'Abdīn was obviously controversial, given his earlier career.

61 MS XII. 5 (IV, 487/III, 18). The patriarch Cyriacus of Takrit is accused of being a Roman collaborator because he had funded church-building across the border. These contacts would have been diplomatically advantageous to the caliph in some circumstances. Also note MS XII. 9 (IV, 500/III, 36) for the rebel Nașr b. Shabath using a Christian secretary to write to the Byzantines. 62 MS XII. 19 (IV, 530/III, 190 -191), for the Nubian embassy to al-Raqqa that met Dionysius. For Sasanian precedents for the use of Christian bishops as diplomats, see Sako 1986.

63 MS XII. 13 (IV, 516/III, 63), for Dionysius' visit to Egypt. Caliphs also employed 'Nestorian' Christians to destroy the churches of other confessions in Egypt and Palestine: Meinardus 1967. 64 MS XI. 25 (IV, 473/II, 523), for the election of Ishaq of Ḥarrān because of his presumed knowledge of alchemy on the recommendation of Akhi, emir of the Jazira. For the wider appeal of Christian specialists in medicine, philosophy and the translation of the Greek classics: Gutas 1998; Tannous 2010. 
jects, a sign of his toleration of the ahl al-kitāb, in accordance with Qur'ānic principles, and the universal reach of his empire. ${ }^{65}$

Caliphal attitudes towards the Jacobite patriarchs never took an interventionist stance regarding points of theology, perhaps because Jacobite theology never had the political salience of Chalcedonianism as the state religion of the Byzantine Empire. ${ }^{66}$ But the period covered here does see the disappearance of confessional groups and the dominance of three Christian confessions (the Church of the East, Chalcedonianism, and Jacobitism) as the orthodox Christianities of the Islamicate world, to the exclusion of others. For instance, when the patriarch of the Church of the East, Timothy I (r. 780-823), issued a general statement on the unity of the faith, he stressed the common beliefs of the Church of the East, the Melkites and the Jacobites in the resurrection and in the saving power of Christ. He passed over in silence other groups that might have called themselves Christian, such as the Marcionites ${ }^{67}$ or the Julianists.

Relations between the Julianists and the Jacobites are a good example of the trend towards the consolidation of Christians into three main confessions. Julian of Halicarnassus was a Miaphysite theologian who had disagreed with Severus, the Miaphysite patriarch of Antioch, in the 520s. ${ }^{68}$ His followers persisted as a distinct group and launched missions from Syria and Egypt into Armenia, South Arabia and Iraq. In other words, they subscribed to an alternative version of the Miaphysite theology from the Jacobites and formed an independent church (though we do not know much of its internal details).

Major efforts towards the reconciliation of the Julianists were made by the patriarch Cyriacus of Takrit at a synod in 798. Gabriel, the Julianist leader, "recognised the stupidity of the doctrine of Julian and agreed to follow the things that we confess". Michael the Syrian reports that Gabriel agreed to include Severus in the diptychs and even accept his anti-Julianist writings, though he would not anathematize Julian himself. Cyriacus and Gabriel then agreed that the names of both men would be proclaimed in the churches and that whoever out-

65 Compare the cosmopolitan self-fashioning of Sasanian shāhs: Payne 2016.

66 For Marwān's intervention in favour of Theophylact bar Qanbara, and his actions against supporters of the Trisagion prayer (probably Maronites in this context), see MS XI. 22 (IV, 467) III, 511). Also note Signes-Codoñer 2014, 396-397, for the extent of communication between Byzantium and the Melkite patriarchates of the east.

67 For the earlier history of the Marcionites in the time of Ephrem, see Bundy 1988. For the presence of Marcionites in the east, see Fiey 1970b.

68 Menze 2008, 152. 
lived the other would reign as sole patriarch. Following this agreement, Cyriacus and Gabriel received communion from one another. ${ }^{69}$

This meeting seems to have been a magnanimous arrangement by Cyriacus to resolve a longstanding separation. However, he faced problems from his own intransigent bishops, who demanded that Gabriel anathematize Julian. Gabriel responded that while he was willing to anathematize Julian, he did not feel that his followers would be prepared to accept this. The Jacobite bishops pressed the point, which ultimately prompted Gabriel to break off negotiations. ${ }^{70}$

One reason for the opposition to reconciliation with Gabriel was likely Cyriacus' own position as an outsider (he was the first 'easterner' to reign as a Jacobite patriarch) and a sense by Jacobite bishops that Gabriel's succession would further remove power from the monasteries that had traditionally produced the patriarch. ${ }^{71}$ But even though the reconciliation with the Julianists failed, the fact that Gabriel was receptive to Cyriacus' overtures may also point to broader changes within the Jacobite church that made union seem attractive at this point. Takrit had become a wealthy trading centre with links to Egypt and the Mediterranean, and a native of Takrit may have been able to tap into these networks in soliciting donations or receiving tithes. ${ }^{72}$ Tithing itself may have become more accepted and systematized as well at this stage: Cyriacus is accused of excessive tithing, suggesting that the process was becoming more regularized. ${ }^{73} \mathrm{We}$ get an indication of Cyriacus' more centralized and proactive governance through his organization of five synods and his investigations into the theology employed at a parish level. ${ }^{74}$ Cyriacus is also the first patriarch for whom Michael the Syrian is able to give a full list of all the bishops he consecrated ( 86 in total), which suggests that his reign was a threshold for major administrative reforms. ${ }^{75}$

The improved organization and wealth of the Jacobite church may have been an incentive to other Miaphysites to seek union. The appointment of Cyriacus himself, an easterner and probably an Arabic speaker, may have sent signals that a compromise was possible; if not on a theological level, then at least for

69 MS XII. 4 (IV, 485/III, 13).

70 MS XII. 4 (IV, 486-7/III, 14-15). One long-term result for Cyriacus was periodic suspicion that he was himself a Julianist: MS XII. 7 (IV, 492/III, 25).

71 For the dominance of Mesopotamia in patriarchal elections, see Hage 1966, 11.

72 Fiey 1969; Immerzeel 2004. The Takritians had permanent colonies in Mosul, al-Raqqa, Nisibis and Egypt: Fiey 1959, 27 note 2.

73 MS XII. 4 (IV, 487/III, 18). The complaints of the Gubbaye monks imply that they had been stripped of an informal exemption from tithes.

74 MS XII. 8 (IV, 496/III, 33).

75 MS Appendix III, 450-53. 
the incorporation of men outside a narrow clique from what had been Roman Mesopotamia.

\section{The Use of Diplomas}

A major mechanism that caliphs used to promote the authority of their Christian appointees, and sometimes to make them independent of local emirs, was the issuing of royal diplomas. These pertained to the right to hold office as patriarch, the right to build new churches and the tax exemptions of individual cities or monasteries.

Michael the Syrian's flagship example of the construction of a new church is the one that was built at the entrance of the patriarch Elias into Antioch, when he came to consecrate the first Jacobite church in the city in 732. It was only constructed thanks to a diploma from Yazìd II. This was a major coup: Antioch was the titular see of the Jacobite patriarch but there had not been a Miaphysite incumbent since the patriarch Severus (d. 538). ${ }^{76}$ It was one of the first signs of public recognition of the Jacobites by the Arab authorities. Other examples of diplomas for church building in this period allowed for the restoration of churches in Edessa, Harrān and Amida and the construction of new churches in Takrit, Mosul, Edessa and Maypherkat. ${ }^{77}$

The construction of new churches was theoretically forbidden according to the shurūt 'Umar imposed upon the dhimmī. These rules were only disseminated under the caliph al-Mutawakkil, but individual parts of this code had been imposed locally before this point, depending on local circumstances. ${ }^{78}$ At several points in Michael's history, Muslim emirs destroy churches built after the Arab conquests. This may be a sign that such rules were promoted by some sections of the Muslim population, perhaps in part because the destruction of churches could be a source of revenue or building materials. ${ }^{79}$

76 MS XI. 19 (IV, 456/II, 491).

77 Hage 1966, 59-61. See also Timothy's intercession with al-Hādī to get churches rebuilt: Fiey 1980, 49, citing Letter 39.

78 Levy-Rubin 2011. There is an on-going debate on the origins and application of the shurūt in the $7^{\text {th }}$ and $8^{\text {th }}$ century, for which see Yarbrough 2016 and Levy-Rubin 2016 on 'Umar II, as well as Noth 2004 and Cohen 1999 on the Rāshidūn and the Umayyad context for discriminatory legislation more generally.

79 Chronicle to 1234, II (10/6) for Ibrāhīm, emir of Harrān, being informed about new church buildings in Edessa by the pagan population of Harrān; MS IV, 478/III, 3, for Mohtasib's destruction of new churches; MS XII. 13 (IV, 513/III, 60 - 61), for Yaqdan's destruction of churches in Takrit and Edessa, especially targeting new buildings. See also al-Azdī's description of how a Mus- 
In an environment where Christian authorities felt threatened by local Muslims wishing to destroy churches and where the destruction of new churches was seen as legitimate, caliphal intervention constituted a suspension of normal rules of behaviour. As has been observed in other authoritarian societies, the primacy of the caliph was underscored by his ability to overturn expected law or custom, in this instance in response to intercession from a patriarch or bishop. ${ }^{80}$ In so doing the caliph confirmed the importance of the patriarch to his flock, and more importantly his own primacy in both the Muslim and Christian hierarchies.

The use of diplomas to confirm tax exemptions had good precedents in the Roman world. Gaining diplomas depended on bishops' diplomatic skills and allowed them to provide wider protection from taxation or political advantage to the towns and monasteries that funded and supported them. There are examples of this from our period from Takrit, ${ }^{81}$ Edessa $^{82}$ and Mosul, ${ }^{83}$ as well as from the monastery of Gubba Barraya near Cyrrhus. ${ }^{84}$

One important difference of these later, Islamic-period diplomas was that they frequently purported to be $7^{\text {th }}$ century historical documents dating back to the Arab conquests. This meant that Muslim authorities could not reject these Christian claims out of hand. The image of the good Muslim ruler included their ability to protect the dhimmī and to respect the treaties concluded by their 'pious forebears' who had conquered the Near East. ${ }^{85}$ And there was sufficient ignorance of the precise details of early conquest treaties that the claims of Christian archives in some cities (Edessa in particular) might be taken seriously during debates over taxation. ${ }^{86}$

Nevertheless, we should also remember that in order for these claims to be convincing, bishops were forced to use a Muslim script. This meant they had to themselves relay a story in which the Muslim conquest was legitimate and Christians (and bishops in particular) collaborated in the conquest of the cities of the Near East. In other words, producing these 'ancient treaties' as proof also meant accepting the terms and validity of the Muslim futūh, according to which resis-

lim mob in Mosul destroyed a church that had taken over a piece of land owned by a mosque (Fiey 1956, 20 -21), and MS XII. 6 (IV, 490/III, 2) for the lucrative destruction of ancient churches in Jerusalem and Aleppo.

80 Brown 1992, 3; Kelly 2004.

81 Bar Hebraeus, Ecclesiastical History, III, 123-126.

82 Chronicle to 1234 , II (3/1).

83 MS XII.14 (IV, 520/III, 69). Note the comments of Robinson 2000, 12.

84 MS XII. 12 (IV, 510/III, 57).

85 Borrut 2005; Khalek 2011, 48.

86 Calder 1993, 121-138. 
tance was futile and Muslim rule natural. In telling a story whereby bishops facilitated the Muslim conquest, these documents also justified a present in which bishops acted on behalf of the Muslim state and obscured alternative histories where local Christian populations supported the Romans or Sasanians.

The use of diplomas to mark the patriarchal office itself is first referred to in the reign of Iwannis, who is said to have received it by offering a bribe to Marwān II after his election by his fellow bishops. His controversial successors David of Dārā, John of Callinicum, Ishaq of Hẹrāan and Athanasius Sandalaya also held patriarchal diplomas from Marwān II or from al-Manșūr. ${ }^{87}$ But it is clear that possession of a diploma did not necessarily guarantee a patriarch the obedience of his flock. For instance, Iwannis was unable to force his metropolitans to accept the popular election of one Dionysius as bishop of Țūr 'Abdīn and was then placed in an embarrassing position when his patron Marwān tried to impose his own candidate Cyriacus of Segestan. ${ }^{88}$ Likewise, Sandalaya may have presumed that his possession of a diploma qualified him to put forward his own candidate for bishop, one Abdani, on the independent-minded see of Harrān. Instead Sandalaya was strangled by the town's citizens. ${ }^{89}$

On the other hand, by the end of the 750s possession of a diploma was a crucial prerequisite for raising tithes. The raising of tithes without a diploma was the key accusation made by David of Dārā against the patriarch George of Beltan, which resulted in George's imprisonment and David's own appointment as patriarch. ${ }^{90}$ The implication is that church tithes were raised in the caliph's name and represented an extension of the symbolic power of the state to its agent the patriarch.

The controversial period between 740-760 was filled with a number of short-lived patriarchs, whom Michael the Syrian often presents as illegitimate. This was a transitional period. Bishops and Christian notables were not yet accustomed to the intervention of the state in elections or the state's endorsement of the rights of the patriarch to raise tithes. At the same time, caliphs sought to impose individual bishops (Cyriacus of Segestan) or patriarchs (the 'alchemist' Ishaq of Harrān) upon the Jacobites, with little long-term success. A more laissez-faire attitude was expressed by al-Ma'mūn when he ordered that a diploma be given to "whoever the Jacobites agree upon": this may recognize that the patriarch's effectiveness would be compromised if he interfered unnecessarily with

87 Hage 1966, 20, 67.

88 MS XI. 14 (IV, 464-5/II, 506-507).

89 MS XI. 25 (IV, 473/II, 523).

90 MS XI. 25 (IV, 477/II, 528). 
the structures of church governance. The elections of Cyriacus of Takrit and Dionysius of Tel-Mahre as patriarch seem to have been much more smooth than their predecessors as a result. ${ }^{91}$

\section{The Emirs, Muslim Citizens and the Bishops}

If the caliphs had a vested interest in patriarchal authority, the same cannot always be said of other Muslim elites, whether government appointees or local aristocracies. $^{92}$

We first hear of an emir of the Jazīra in the Chronicle of Michael the Syrian when one named Muhammad crucifies local Christian notables in the 690s. This was probably part of a state drive to increase revenue by making prominent examples of elites who resisted tax demands. ${ }^{93}$ His successors Mūsā b. Muṣ áa and Mūsā b. Sulaymān ruled the Jazīra and Qennesrin in the 770s and were also associated with the violent collection of taxes: the Chronicle of Zuqnin reports Mūsā's ruthless pursuit of the poll tax after conducting a detailed census and audits even during a time of famine and plague. ${ }^{94}$ Precise knowledge of estate yields and accumulated wealth was crucial for governors to extract taxes and for caliphs to monitor how much revenue eventually found its way to Baghdad. Chase Robinson has suggested that the relentless squeezing of the peasantry (both Christians and more recently settled Arab Muslims) was a consequence of the demands of a Baghdad government that took no account of local volatility in prices and production but needed to pay a large standing army in coin rather than kind..$^{95}$

Later governors continued to be effective and much-resented seekers after tax revenue. Dionysius, for example, complains about the agents sent by Hārūn al-Rashīd to find the fabled wealth of the Rusafaye family (of which he was a descendant): he protests, probably falsely, that the riches have long been frittered away. ${ }^{96}$ Dionysius also narrates the zealous acts of governors such as Yaqdan of Edessa, who forced the citizens to free their slaves in order to make them Muslims, ${ }^{97}$ or Ali of Damascus, who targeted the sons of rich

91 MS XII. 12 (IV, 511/III, 57).

92 For these two groups in Mosul, see Kennedy 1981.

93 MS XI. 16 (IV, 447/II, 473).

94 MS XI. 26 (IV, 476/II, 526).

95 Robinson 2016.

96 MS XII. 4 (IV, 485/III, 13).

97 MS XII. 13 (IV, 514/III, 62). 
men who had recently died and accused them of patricide. ${ }^{98}$ Dionysius places this 'injustice' against a background of an expanding infrastructure of governance; he describes, as though writing of a novelty, the installation of a judge ("called a qadi") at al-Raqqa who oversaw taxes, supported by a prefect and a courier system. ${ }^{99}$

Here it is worth stressing the difference in perspective between Dionysius and the Chronicle of Zuqnin. The Chronicle of Zuqnin presents the suffering inflicted by Mūsā b. Muṣ'ab as universal: it is a mark of the apocalypse and afflicts people of all religions and classes. ${ }^{100}$ Dionysius is more concerned with the fates of noble families and their wealth. As a member of the elite families of the Gumaye and Rusafaye, one of the purposes of his Chronicle is to retell his own family history (interwoven with the history of the church), both to legitimize his family's importance and to evoke sympathy for its misfortunes.

The government appetite for effective tax information may have made elite families much more vulnerable to those who would inform against them. In other words, as a consequence of a newly intrusive state local elites had a vested interest in social solidarity that they might not have a generation before. One example of this comes in a scene just after the 'Abbāsid revolution, when a Persian denied lodging by the Gumaye at Baghdad accused them of Manichaeism. This religion was banned by the caliphate, as it was by the Romans, and the accusation was always a good claim to make against any intellectual or cultural elite. ${ }^{101}$ That this kind of denunciation was a serious threat indicates the ease with which information flowed between the capital and the Jazira. This in turn may point to the interlinking of provincial social networks in the aftermath of the revolution.

The flow of information to the capital was, however, a negative development for elites whose status and interests were not at that stage sustained by service to the state. In other words, while the 'Abbāsid revolution facilitated the involvement of Muslims of diverse origins in the state by giving them resources and influence, it also encouraged Christian elite families to re-fashion themselves as a service elite whose links to court could protect them from the envious.

An increasingly common route for information to reach governors to the detriment of the Christian population was via their Muslim and pagan neighbours. Muslims in Edessa reportedly encouraged looting by invading armies during the

98 MS XII. 21 (IV, 539/III, 104).

99 MS XII. 21 (IV, 538/III, 105). See further Silverstein 2007, ch. 2.

100 Chronicle of Zuqnin, 316/273.

101 Cf. Arjomand, 1994; Chokr 1993. For the accusations of human sacrifice made against Manicheans at Ḥarrān, see Chronicle of Zuqnin, 224-225/203. 
fourth fitna. ${ }^{102}$ Pagans in Ḥarrān (possibly a local majority) allegedly encouraged the emir Ibrāhīm to destroy churches and synagogues. ${ }^{103}$ And Ḥarrānian Muslims raided Christian properties during Yaqdan's actions against Christian slave-owners in Edessa. ${ }^{104}$ In these cases local non-Christian populations may have been sources of information for emirs who were outside appointees, as well as a physical support to any emir who wanted to penalize the Christian population.

In the event of a local emir treating the Christian population unfairly, it was often possible for the patriarch to appeal to a higher-ranking governor or to the caliph. For instance, when Yaqdan demolished Jacobite churches in Edessa and freed the slaves of the Christians, Dionysius successfully appealed to 'Abdallāh, the governor of al-Raqqa and a relative of the caliph, to put a stop to it. ${ }^{105}$ Dionysius was able to use his influence at court to prevent further demolition, but he could not do so by appealing to Yaqdan directly. Sponsorship and employment by the caliph could mitigate but not eliminate the vulnerability of the Jacobites of Edessa to a governor who was opposed to them. Indeed this vulnerability exaggerated Dionysius' dependency on the caliph and the 'Abbāsid family.

Appeals by the patriarch or bishops to the administration could not work in situations where the state was essentially taken over by kin-groups. An example of this occurs with the exactions of one Aḥmad b. Abī Dāwūd, a member of the Iyād tribe who abused his government position to make free Christians perform corvée labour and overtaxed estates to force owners to sell to members of his family. ${ }^{106}$ In this case, Ahmad's obligations to his relatives may have motivated him to use governmental structures in their interests, while the presence of large numbers of the Iyād in his district acted as a disincentive to other state actors to challenge his power. I suggest that tribal groups who had recently acquired roles on behalf of the state were especially difficult for Christian leaders to negotiate with. Incidentally, the inability of Dionysius to protect Christians from the Iyād in the way he had from Yaqdan also points to a wider vulnerability of the 'Abbāsid state, whereby tribal groupings could circumvent the normal systems of reward and censure.

102 MS XII. 6 (IV, 492/III, 22).

103 MS XII. 11 (IV, 505/III, 47).

104 MS XII. 13 (IV, 514/III, 62).

105 MS XII. 13 (IV, 514/III, 62).

106 MS XII. 21 (IV, 540-2/III, 107-111). 


\section{Conclusions}

I have suggested that episcopal and monastic networks represent a survival of Roman-era notions of territoriality that endured under Muslim rule. Over time, these Christian structures were incorporated into 'Abbāsid imperial structures. In the case of the Jacobites, the episcopacy remained vulnerable at a local level. This intensified their reliance on the caliph.

Several turning points are apparent in the sources. The first is the dramatic increase in the quantity and complexity of historical material available from the 740s (from the reign of Iwannis onwards). This may be a function of the transfer of the caliphal capital to Harrān under Marwān II, which provided much easier access to the caliph. The move opened up new possibilities for advancement that threatened the monopoly of the great monasteries (though it still tended to favour candidates from former Roman Mesopotamia over those from Syria or Takrit). The need to legitimise or condemn the new practices of the time may have themselves spurred a generation of historians.

The period 740-780 also sees the first use of caliphal diplomas. These provided licences to tithe parishioners, construct churches and call bishops to council. We should see this as an instance of the Jacobite church mimicking (and drawing on) the ability of the state to tax and coerce. It made the office of the patriarch both more lucrative and effective.

The escalation of the powers of the patriarch occurs against a wider background of pressure against lay aristocrats, through regular state taxation by the state, extortion by state servants acting in their own interests, or denunciations by local opponents. These phenomena seem to have accelerated markedly after the 'Abbāsid revolution, and I suggest that this led Christian elites to place a higher premium on Königsnähe, in order to protect property from a variety of threats. However, a critical difference that we should note between courtly influence in the Roman and 'Abbāsid periods was that Christian clergy were increasingly seen as the main representatives of their communities (even where others held power behind the throne), and that clerical rank became a key means to secure influence with Muslim rulers.

Dionysius' history can be read as an example of how one aristocratic family adapted to these changing circumstances by seeking a rank in the higher clergy. He is at pains to stress his noble lineage back to the $6^{\text {th }}$ century and draw on family histories written by his ancestors to do so. ${ }^{107}$ His inherited cultural capital, as

107 E.g. MS XII. 4 (IV, 485/III, 13), for the story of how Hārūn al-Rashīd sent a tax collector to seize the treasures of the Rusafaye and Gumaye families, both ancestors of Dionysius. 
a man schooled in Arabic and courtly speech ${ }^{108}$ as well as in Syriac, made him (at least in his own representation) such a suitable candidate for the patriarchate that the other bishops elected him without his having been ordained (he was only a monk of Qenneshre at the time). ${ }^{109}$ Like Ambrose of Milan or Synesius of Cyrene, his training and connections as an aristocrat were seen to be more useful to the church than ascending the traditional ladder of promotion, in a context where the patriarch had become part of al-Ma'mūn's service elite.

\section{Jacobite patriarchs of Antioch, giving the year of consecration (after Hage 1964)}

$\begin{array}{ll}\text { Iwannis } & 739 / 40 \\ \text { Ishaq } & 754 / 5 \\ \text { Athanasaius Sandalaya } & 755 / 6 \\ \text { George } & 758 \text { (deposed between } 766 / 7-775) \\ \text { John of Callinicum } & 758 / 9 \\ \text { David of Dārā } & 766 / 7 \\ \text { Joseph of Gubba Barraya } & 790 \\ \text { Cyriacus of Takrit } & 793 \\ \text { Dionysius of Tel-Mahre } & 818 \\ \text { John } & 845\end{array}$

\section{Bibliography}

\section{Primary sources}

Bar Hebraeus (1872-1877), Ecclesiastical History, ed. and tr. by Jean Baptiste Abeloos and Thomas Lamy, Gregorii Barhebraei chronicon ecclesiasticum, 3 vols., Paris/Louvain: Peeters.

Chronicle to 1234 (1916-1920), ed. by Jean-Baptiste Chabot, Chronicon Anonymum ad Annum Christi 1234 Pertinens, CSCO 81-2, Scriptores Syri 36-7, 2 vols., Louvain: CSCO. Latin trans. of Scriptores Syri 36 by J.-B. Chabot (1937) in Scriptores Syri 56, and French trans. of Scriptores Syri 37 by A. Abouna and J.-M. Fiey (1974) in Scriptores Syri 154. Chronicon ad annum Domini 846 pertinens (1904), ed. and tr. by E. W. Brooks, Chronica Minora II, CSCO 3, Scriptores Syri 3, Louvain: CSCO.

Garshuni Life of Theodota of Amida, tr. by Jack Tannous (unpublished text). Life of Ahudemmeh (1909), ed. and trans. by François Nau, Patrologia Orientalis 3, Paris:

Firmin-Didot, 7-51.

108 For a set-piece display of his virtuoso abilities in his meeting with al-Ma'mūn, see MS XII. 14 (IV, 517/III, 65ff.).

109 For his ordination, see MS XII. 10 (IV, 502/III, 41). 
Mārī b. Sulaymān (1899), Kitāb al-Majdal, ed. and tr. by H. Gismondi, Maris, Amri, et Salibae: De Patriarchis Nestorianorum Commentaria II: Maris textus arabicus et versio Latina, Rome: De Luigi.

Michael the Syrian (1899-1910), Chronicle, reproduced [vol. IV] and trans. [vols. I-III] by Jean-Baptiste Chabot, 4 vols., Paris: Leroux.

Synodicon orientale (1902), ed. and tr. by Jean-Baptiste Chabot, Paris: Impr. Catholique.

The Synodicon in the West Syrian Tradition (1975-1976), ed. and tr. by Arthur Vööbus, CSCO 375-76, Scriptores Syri 163-64, Louvain: Peeters.

Chronicle of Zuqnin (1927), ed. by Jean Baptiste Chabot, Incerti auctoris Chronicon Pseudo-Dionysianum vulgo dictum II, Paris/Louvain, CSCO 104, Scriptores Syri 53: Peeters; tr. by Amir Harrak (1999), The Chronicle of Zuqnin, Parts III and IV A.D. 488-775, Translated from Syriac with Notes and Introduction, Toronto: Pontifical Institute of Medieval Studies.

\section{Studies}

Arjomand, Said Amir (1994), “'Abd Allah Ibn Al-Muqaffa' and the 'Abbāsid Revolution”, Iranian Studies 27/1-4: 9-36.

Bates, Michael (1984), "Byzantine Coinage and Its Imitations, Arab Coinage and Its Imitations: The Byzantine-Arab Coinage”, Aram 6: 381-403.

Borrut, Antoine (2005), "Entre tradition et l'histoire: Genèse et diffusion de l'image de Umar II”, Mélanges de l'Université de S. Joseph 53: 329-378.

Brock, Sebastian (1996), "Nestorian Church: A Lamentable Misnomer”, Bulletin of the John Rylands Library 78: 23-53.

Brown, Peter R. L. (1992), Power and Persuasion in Late Antiquity: Towards a Christian Empire, Madison: University of Wisconsin Press.

Bundy, David (1988), “Marcion and the Marcionites”, Le Museon 101: 3-32.

Cabrol, Cécile (2012), Les secrétaires nestoriens à Bagdad (762-1258 AD), Beirut: Centre de recherches et de publications de l'Orient chrétien (CERPOC), Faculté des sciences religieuses, Université Saint-Joseph.

Cabrol, Cécile (2000), "Une étude sur les secrétaires nestoriens sous les Abbassides 762-1258 à Bagdad”, Parole de l'Orient 25: 407-91.

Calder, Norman (1993), Studies in Early Muslim Jurisprudence, Oxford: Oxford University Press.

Chamberlain, Michael (1994), Knowledge and Social Practice in Medieval Damascus, 1190-1350, New York: Cambridge University Press.

Chediath, Geevarghese (1982), The Christology of Mar Babai, the Great, Kottayam, India: Oriental Institute of Religious Studies.

Chokr, Melhem (1993), Zandaqa et zindīqs en Islam au second siècle de l'hégire, Damascus: Institut francais de Damas.

Cobb, Paul (2001), White Banners: Contention in 'Abbāsid Syria, 750-880, Albany, NY: State University of New York Press.

Cohen, Mark (1999), "What was the Pact of Umar? A Literary-Historical Study”, Jerusalem Studies in Arabic and Islam 23: 100-158. 
Debié, Muriel (2016), "Christians in the Service of the Caliph: Through the Looking Glass of Communal Identities", in: Antoine Borrut and Fred McGraw Donner, eds., Christians and Others in the Umayyad State, Chicago: University of Chicago Press, 53-72.

Donner, Fred McGraw (2010), Muhammad and the Believers: At the Origins of Islam, Cambridge, MA: The Belknap Press of Harvard University Press.

Edelby, Neophyte (1951), “L'autonomie législative des chrétiens en terre de l'Islam”, Archive d'histoire du droit orientale 5: 307-351.

Fiey, J. M. (1959), Mossoul chrétienne. Essai sur l'histoire, l'archéologie et l'état actuel des monuments chrétiens de la ville de Mossoul. [With Plates, Including Plans.], Beirut: Impr. catholique.

Fiey, J. M. (1963), “Tagrit. Esquisse de l'histoire chrétienne”, L’Orient Syrien 8: 289-342.

Fiey, J. M. (1970a), Jalons pour une histoire de l'église en Iraq, Louvain: CSCO.

Fiey, J. M. (1970b), “Les marcionites dans les textes historiques de l'église perse”, Le Museon 83: $183-87$.

Fiey, J. M. (1980), Chrétiens syriaques sous les Abbassides surtout à Bagdad, 749-1258, Louvain: CSCO.

Griffith, Sidney Harrison (1989), “Anthony David of Baghdad, Scribe and Monk of Mar Sabas: Arabic in the Monasteries of Palestine", Church History 58: 7-19.

Griffith, Sidney Harrison (1998), "The Monks of Palestine and the Growth of Christian Literature in Arabic", The Muslim World 78: 1-28.

Griffith, Sidney Harrison (2008), The Church in the Shadow of the Mosque: Christians and Muslims in the World of Islam, Princeton, N.J.: Princeton University Press.

Gutas, Dimitri (1998), Greek Thought, Arab Culture: The Graeco-Arabic Translation Movement in Baghdad and Early 'Abbāsid Society (2nd-4th/8th-10th C.), New York/London: Routledge.

Gyselen, Rika (2009), Arab-Sasanian Copper Coinage, Vienna: Verlag der Österreichischen Akademie der Wissenschaften.

Hage, Wolfgang (1996), Die syrisch-jakobitische Kirche in frühislamischer Zeit, nach orientalischen Quellen, Wiesbaden: Harrassowitz Verlag.

Halsall, Guy (2007), Barbarian Migrations and the Roman West, 376-568, Cambridge: Cambridge University Press.

Hoyland, Robert (2003), "The Twin Histories of Arabic and Aramaic. (And: Why Did Aramaic Succeed Where Greek Failed?)”, Scripta Classica Israelica 23: 183-99.

Humfress, Caroline (2005), "Law and Legal Process in the Age of Justinian”, in: M. Maas, ed., The Cambridge Companion to the Age of Justinian, Cambridge: Cambridge University Press, $161-85$.

Immerzeel, Matt (2004), “The Stuccoes of Deir Al-Surian: A Waqf of the Takritians in Fustat?", in: Matt Immerzeel and Jan Van der Vliet, eds., Coptic Studies on the Threshold of a New Millennium II. Proceedings of the Seventh International Cingress of Coptic Studies, Leiden: Brill, 1303-1320.

Ivanov, Sergei (2015), "Pearls before Swine": Missionary Work in Byzantium, trans. by Deborah Hoffmann, Paris: College de France/CNRS.

Jones, A.H.M. (1964), The Later Roman Empire, 284-602: A Social, Economic and Administrative Survey, 3 vols., Oxford: Oxford University Press.

Kelly, Christopher (2004), Ruling the Later Roman Empire, Cambridge, M.A.: Harvard University Press. 
Kennedy, Hugh (1981), "Central Government and Provincial Elites in the Early 'Abbāsid Caliphate", Bulletin of the School of Oriental and African Studies 44: 26-38.

Keser-Kayaalp, Elif (2013), “Églises et monastères du Ṭur 'Abdin: les débuts d'une architecture "syriaque “”, in: F. Briquel-Chattonet, ed., Les églises en monde syriaque, Paris: Geuthner, 269-288.

Keser-Kayaalp, Elif (2016), “Patronage of Churches in Late Antique Northern Mesopotamia”, in: C. Kapitoğlu, E. Yavuz, and B. Tabibi, eds., Spaces/Times/Peoples: Patronage and Architectural History, Ankara: Ödtu, 43-56.

Khalek, Nancy A. (2011), Damascus after the Muslim Conquest: Text and Image in Early Islam, Oxford/New York: Oxford University Press.

Leeming, Kate (2003), "The Adoption of Arabic as a Liturgical Language by the Palestinian Melkites”, ARAM 15: 239-246.

Levy-Rubin, Milka (2016), “Umar Il's ghiyār Edict: Between Ideology and Practice”, in: Antoine Borrut and Fred Donner, eds., Christians and Others in the Early Islamic State, Chicago: Oriental Institute, 157-172.

Levy-Rubin, Milka (2011), Non-Muslims in the Early Islamic Empire: From Surrender to Coexistence, New York: Cambridge University Press.

Liebeschuetz, J. H. W. G. (2001), Decline and Fall of the Roman City, Oxford: Oxford University Press.

Meinardus, Otto (1967), “The Nestorians in Egypt”, Oriens Christianus 15: 114-129.

Menze, Volker-Lorenz (2008), Justinian and the Making of the Syrian Orthodox Church, Oxford: Oxford University Press.

Morony, Michael (1984), Iraq after the Muslim Conquest, Princeton: Princeton University Press.

Norton, Peter (2007), Episcopal Elections 250-600: Hierarchy and Popular Will in Late Antiquity, Oxford Classical Monographs, Oxford: Oxford University Press.

Oez, Mikael (2012), Cyriacus of Takrit and His Book on Divine Providence, 2 vols., Piscataway, N.J.: Gorgias Press.

Palmer, Andrew (1990), Monk and Mason on the Tigris Frontier: The Early History of Tur 'Abdin, Cambridge: Cambridge University Press.

Papaconstantinou, Arietta (2012), "Why Did Coptic Fail Where Aramaic Succeeded? Linguistic Developments in Egypt and the Near East after the Arab Conquest”, in: A. Mullen and P. James, eds., Multilingualism in the Graeco-Roman Worlds, Cambridge: Cambridge University Press, $58-76$.

Papaconstantinou, Arietta (2008), "Between umma and dhimma: The Christians of the Middle East under the Umayyads", Annales Islamologiques 42: 127-56.

Payne, Richard (2009), "Persecuting Heresy in Early Islamic Iraq: The Catholicos Isho'yahb III and the Elites of Nisibis", in: A. Cane and N. Lenski, eds., The Power of Religion in Late Antiquity, Ashgate: Variorum, 397-410.

Payne, Richard (2015a), A State of Mixture: Christians, Zoroastrians, and Iranian Political Culture in Late Antiquity, Berkeley/London: University of California Press.

Payne, Richard (2015b), “East Syrian Bishops, Elite Households, and Iranian Law after the Islamic Conquests”, Iranian Studies 48: 5-32.

Payne, Richard (2016), "Iranian Cosmopolitanism: World Religions at the Sasanian Court”, in: Myles Lavan, Richard Payne, and John Weisweiler, eds., Cosmopolitanism and Empire: 
Universal Rulers, Local Elites and Cultural Integration in the Ancient Near East and Mediterranean, Oxford: Oxford University Press, 209-230.

Putman, Hans (1975), L'Église et l'Islam sous Timothée I (780-823): étude sur l'église nestorienne au temps des premiers 'Abbāsides, Beirut: Dar el-Machreq.

Rapp, Claudia (2005), Holy Bishops in Late Antiquity: The Nature of Christian Leadership in an Age of Transition, Berkeley/London: University of California Press.

Robinson, Chase F. (2005), 'Abd al-Malik, London: OneWorld.

Robinson, Chase F. (2016), “Al-'Attāf b. Sufyān and 'Abbāsid Imperialism”, in: Alireza Korangy et al., eds., Essays in Islamic Philology, History and Philosophy, Berlin: De Gruyter, $357-385$.

Robinson, Chase F. (2000), Empire and Elites after the Muslim Conquest. The Transformation of Northern Mesopotamia, Cambridge: Cambridge University Press.

Sako, Louis (1986), Le rôle de la hiérarchie syriaque orientale dans les rapports diplomatiques entre la Perse et Byzance aux Ve-VIle siècles, Paris: Université de Paris IV.

Schor, Adam M. (2011), Theodoret's People: Social Networks and Religious Conflict in Late Roman Syria, Berkeley/London: University of California Press.

Signes-Codoñer, Juan (2014), The Emperor Theophilos and the East, 829-842: Court and Frontier in Byzantium During the Last Phase of Iconoclasm, Ashgate: Variorum.

Silverstein, Adam J. (2007), Postal Systems in the Pre-Modern Islamic World, Cambridge/New York: Cambridge University Press.

Simonsohn, Uriel (2010), “The Christians Whose Force Is Hard: Non-Ecclesiastical Judicial Authorities in the Early Islamic Period", Journal of the Economic and Social History of the Orient 53/4: 579-620.

Simonsohn, Uriel (2011), A Common Justice: The Legal Allegiances of Christians and Jews under Early Islam, Philadelphia: University of Pennsylvania Press.

Simonsohn, Uriel (2015), “Justice”, in: Guy Stroumsa, ed., The Oxford Handbook of the Abrahamic Religions, Oxford: Oxford University Press, 137-165.

Tannous, Jack (2010), Syria Between Byzantium and Islam: Making Incommensurables Speak, $\mathrm{PhD}$ dissertation, Princeton University.

Taylor, David (2002), "Bilingualism and Diglossia in Late Antique Syria and Mesopotamia”, in: J. Adams, Simon Swain, and M. Janse, eds., Bilingualism in Ancient Society: Language Contact and the Written Word, Oxford: Oxford University Press, 298-331.

van Rompay, Lucas (2008), "Severus, Patriarch of Antioch (512-518), in the Greek, Syriac, and Coptic Traditions", Journal of the Canadian Society for Syriac Studies 8: 3-22.

Vollandt, Ronnie (2015), Arabic Versions of the Pentateuch: A Comparative Study of Jewish, Christian and Muslim Sources, Leiden/Boston: Brill.

Walker, Joel (2006), The Legend of Mar Qardagh: Narrative and Christian Heroism in Late Antiquity, Berkeley: University of California Press.

Wasserstein, David (2003), “Why Did Arabic Succeed Where Greek Failed?", Scripta Classica Israelica 22: 257-272.

Wickham, Chris (2014), “Administrators' Time: The Social Memory of the Early Medieval State, East and West", in: Asad Ahmed et al., eds., Islamic Cultures, Islamic Contexts. Essays in Honour of Patricia Crone, Leiden: Brill, 430-467.

Wickham, Chris (2005), Framing the Early Middle Ages: Europe and the Mediterranean 400-800, Oxford: Oxford University Press. 
Wood, Philip (forthcoming), 'Christianity in the Arabian Peninsula', in: Guillaume Dye, ed., Proceedings of the Early Islamic Studies Seminar.

Wood, Philip (2017), “Christians in Umayyad Iraq”, in: Andrew Marsham and Alain George, eds., The Umayyads: History, Art and Culture in the First Century of Islam, Oxford: Oxford University Press, 255-274.

Wood, Philip (2015), “Christians in the Middle East, 600-1000: Conquest, Conversion and Competition”, in: Andrew Peacock, Bruno Da Nicola, and Sara Nur-Yildiz, eds., Islam and Christianity in Medieval Anatolia, Farnham: Ashgate, 23-50.

Wood, Philip (2013), The Chronicle of Seert: Christian Historical Imagination in Late Antique Iraq, Oxford: Oxford University Press.

Wood, Philip (2010), “We Have No King but Christ”: Christian Political Thought in Greater Syria on the Eve of the Arab Conquest (c.400-585), Oxford: Oxford University Press.

Yarbrough, Luke (2016), "Did 'Umār b. 'Abd al- 'Azīz Issue an Edict Concerning Non-Muslim Officials?”, in: Antoine Borrut and Fred Donner, eds., Christians and Others in the Early Islamic State, Chicago: Oriental Institute, 173-206.

Zakeri, Mohsen (1995), Sāsānid Soldiers in Early Muslim Society. The Origins of 'Ayyārān and Futuwwa, Wiesbaden: Harrassowitz Verlag. 
